\title{
Changes of microbial load in packet orange juice after expiration date
}

\author{
Farahnaaz Feroz* \\ Department of Microbiology, Stamford University Bangladesh, 51, Siddeswari Road, Dhaka 1217, Bangladesh
}

Received 18 July 2018/Accepted 24 August 2018

\begin{abstract}
Fruit juice is popular product in the markets worldwide, with a market potential of approximately 230 million liters. Fruit juice although nutritious and beneficial for health can also serve as a vehicle for foodborne diseases. Most commercially available products are labelled with a use by date. These are applicable at a consumer and food handler levels, instructing them on the amount of days after opening within which a product must be consumed. It is important to identify the changes that occur after expiration date to have a better understanding of when food spoilage occurs and how long foods may be preserved, in order to reduce food wastage. The current study attempted to identify the changes that occur in orange juice after the expiration date printed on the product packaging. One to seven days after expiration results showed very little change. Increase in the microbial load was observed after day 14, after which a steady increase was observed in total viable bacteria, fungus, $E$. coli. and Staphvlococcus spp. No changes were observed in other examined organisms.
\end{abstract}

Key words: Fruit juice; Date expired juice; Microbial quality; Public health

Fruit juice is popular product in the markets worldwide, with a market potential of approximately 230 million liters $(1,2)$. Along with its likable taste it also possesses various nutrients, bioactive compounds and vitamins such as Vitamin C (3-6). Its popularity can also be attributed to the quick paced lifestyle of modern times, where access to convenient and complete nutrition is very important (7). The composition of most commercially available fruit juices include water, sugar, color, preservatives, fruit pulps, carbohydrate, proteins, minerals, Vitamin $\mathrm{A}$ and $\mathrm{C}$, cholesterol and other additives (1, 3-6).

Juices can also serve as a vehicle of food borne illness, allowing the growth of spoilage causing microorganisms in its nutrient rich medium (6-8). In most cases pasteurization is able to eliminate most pathogens but some manage to remain in dormant forms $(2,9)$. The major source of contamination is the water used in the products, others include $\mathrm{pH}$, hygienic practices and temperature (10-12). Raw materials, returned bottles and aerial vectors can also be considered as factors contributing to spoilage of juices $(10,13)$.

Most commercially available products are labelled with a use by date. These are applicable at a consumer and food handler levels, instructing them on the amount of days after opening within which a product must be consumed (14). It is difficult for manufacturers to

*Corresponding Author: Mailing address. Dr. Farahnaaz Feroz, Assistant Professor, Department of Microbiology, Stamford University Bangladesh, 51 Siddeswari Road, Dhaka 1217, Bangladesh; E-mail: farahnaaz@stamforduniversity.edu.bd. establish an accurate use by date due to practical limitations such as the marketplace complexities (15). Often, tests such as Accelerated Shelf-Life tests (ASLTs) are used to identify shelf life by selecting and analysing kinetic elements which are responsible for contamination as well as calculate what the shelf life might be in storage conditions (16). Spoilage refers to microbiological changes as well as the presence of clouds, discoloration, presence of particulates and gas buildup $(13,17)$. These changes indicate how long a product is deemed safe for the consumers. How long after the factory declared sellby or use by date, do these changes and the first indications of spoilage occur.

The current study attempted to identify the changes that occur in orange juice after the expiration date printed on the product packaging. This study attempts to report on the changes that occur in orange juice after it has expired and also to determine the proper time at which a product can be discarded.

\section{MATERIALS AND METHODS}

Sample collection. All samples were purchased from supermarkets and transported to the laboratory as soon as possible. Conditions were kept as close to household practices as possible.

Microbiological analysis. $1 \mathrm{ml}$ of each sample was subjected to serial dilution up to $10^{-3}$ after which they were plated on Nutrient agar and incubated at $37{ }^{\circ} \mathrm{C}$ for 24 hours for total viable bacteria. It was also plated on Sabouraud Dextrose Agar and incubated at $25{ }^{\circ} \mathrm{C}$ for 48 hours for fungal count. Juice was also plated on Mannitol Salt Agar (MSA) and MacConkey Agar (MAC) for the detection of Staphylococcus spp. and Escherichia coli, respectively. Biochemical tests were performed to confirm the identity of the pathogens. Cetrimide agar, Listeria agar, Salmonella-Shigella agar and Thiosulfate-citrate-bile salts-sucrose agar for the detection of Pseudomonas, Listeria, Salmonella and Vibrio spp., respectively (6-8, 18). 


\section{RESULTS AND DISCUSSION}

Fruit juice remains a popular product due to some nutritional benefit it possesses, yet it continues to serve a vehicle of food borne illnesses (1, 6-8, 11). Current study attempted to observe the changes in microbial growth in fruit juice after the factory set use by date. Being able to assess the changes after expiration, will allow consumers to have a better understanding of when food products are safe for consumption. This will also contribute towards less food wastage, as foods will not be thrown away just because of the date on the packets. It will also provide consumers with a guideline. Packet fruit juice, purchased from a super-shop was used in the experiment. Tests of this nature, which rely on predictive microbiology and risk assessment may serve as a guideline towards improving the standards of fruit juices allowing the interpretation of the behavior of microorganisms and pathogens which cause spoilage (3, 6-8).

As seen in Table 1, a sample of packet fruit juice exhibited counts of $10^{4} \mathrm{cfu} / \mathrm{ml}$ of total viable bacteria (TVB). No other bacterial growth was observed before expiration. Results of TVB before expiration seen in the current study, are similar to that of Noor et al. (11), as they also found their counts of TVB to be within the range of $10^{4} \mathrm{cfu} / \mathrm{ml}$. Study by Khanam et al. (12) found TVB ranging from $10^{5}$ to $10^{8} \mathrm{cfu} / \mathrm{ml}$, before expiration. Their counts of fungus were above $10^{5} \mathrm{cfu} / \mathrm{ml}$, whereas this study found no fungus. As seen in Table 2, 1 to 7 days after expiration results showed minimal changes. Increase in the microbial load was observed after day 14 after which a steady increase was observed in TVB, fungus, E. coli, and Staphylococcus spp. No changes were observed in other examined organisms. Sufficient data was not available on the growth of microorganisms
TABLE 1. Presence of microorganisms in packed orange juice before expiration date

\begin{tabular}{cc}
\hline Organism & $\begin{array}{c}\text { Packed orange juice before } \\
\text { expiration }(\mathbf{c f u} / \mathbf{m l})\end{array}$ \\
\hline Total viable bacteria & $1.4 \times 10^{4}$ \\
Total fungus & 0 \\
E coli & 0 \\
Staphylococcus spp. & 0 \\
Pseudomonas spp. & 0 \\
Listeria spp. & 0 \\
Salmonella & 0 \\
Vibrio spp. & 0 \\
\hline
\end{tabular}

after expiration date from other studies as they mostly reported on those which are still consumable state. This increases the importance of the current study, as it allows the better understanding of the patterns of spoilage microorganisms after expiration date, particularly due to the difficulty involved in monitoring the effect of spoiled foods on the consumers (1-19).

\section{CONCLUSIONS}

The standards of fruit juices available in Bangladesh need to be improved as most studies have shown high counts prior to expiration. It is also to be noted that significant changes in microbial growth after expirations was only observed after 14 days from the date. The current study used imported fruit juice, which showed lower levels of microorganism and according to the result of the study, it can be assumed that the juice is safe for consumption between 10 to 13 days after expiration.

TABLE 2. Presence of microorganisms in packed orange juice samples after expiration date

\begin{tabular}{cccccc}
\hline \multirow{2}{*}{ Organism } & \multicolumn{5}{c}{ Packed orange juice after expiration (cfu/ml) } \\
\cline { 2 - 5 } & Day $\mathbf{1}$ & Day $\mathbf{7}$ & Day 14 & Day 21 & Day 28 \\
\hline TVB & $1.6 \times 10^{4}$ & $2.9 \times 10^{4}$ & $3.1 \times 10^{5}$ & $3.2 \times 10^{5}$ & $4.5 \times 10^{7}$ \\
Total fungus & 0 & 0 & $1.5 \times 10^{2}$ & $2.6 \times 10^{2}$ & $1.5 \times 10^{3}$ \\
E. coli & 0 & 0 & $3.0 \times 10^{1}$ & $4.5 \times 10^{2}$ & 0 \\
Staphylococcus spp. & 0 & $1.0 \times 10^{2}$ & $3.9 \times 10^{2}$ & $1.9 \times 10^{3}$ & $4.5 \times 10^{4}$ \\
Pseudomonas spp. & 0 & 0 & 0 & 0 & 0 \\
Listeria spp. & 0 & 0 & 0 & 0 & 0 \\
Salmonella spp. & 0 & 0 & 0 & 0 & 0 \\
Vibrio spp. & 0 & 0 & 0 & 0 & 0 \\
\hline
\end{tabular}

*Day refers to days after expiry date. 


\section{REFERENCES}

1. Wistreich G, Lechtman M. 1988. Microbiology, $5^{\text {th }}$ ed. CollierMacmillan, New York.

2. Huang R, Li M, Gregory RL. 2011. Bacterial interactions in dental biofilm. Virulence. 2 (5): 435-444.

3. Clarke JK. 1924. On the bacterial factor in the etiology of dental caries. British J. Expert Pathol. 5: 141-7.

4. Zambon JJ, Kasprzak SA. 1995. The Microbiology and histopathology of human root caries. American J. Dentistry. 8: 323-328.

5. Marchant S. 2001. The predominant microflora of nursing caries lesions Caries Res. 35 (6): 397-406.

6. Tiwari KB, Shrestha UT, Acharya A, Subedi B, Paudyal B, Jnawali M, et al. 2008. Antibacterial activities of locally used toothpaste against dental pathogens .journal of institute of medicine. 30 (2): 15-18.

7. Arweiler NB, Auschill TM, Reich E, Netuschil L. 2002. Substantivity of toothpastslurries and their effect on reestablishment of the dental biofilm. J. Clin. Periodontol. 29: 615-621.

8. Davies RM .2008. Toothpaste in the control of plaque/gingivitis and periodontitis. Periodontol. 2000. 48: 23-30.

9. Roopavathi KM, Gopal SV, Pushpalatha G, Bennadi D, Renushri BV, Madhura AS. 2015. Antimicrobial efficacy of commercially available toothpastes - An in vitro Study. Journal of Young Pharmacists. 7(3):187193

10. Hammes F, Boon N, de Villiers J, Verstraete W, Siciliano SD. 2003. Strain-specific ureolytic microbial calcium carbonate precipitation. Appl Environ Microbiol. 69: 4901-4909.
11. Noor R, Uddin MA, Haq MA, Munshi SK, Acharjee M, Rahman MM. 2013. Microbiological study of vendor and packed fruit juices locally available in Dhaka city, Bangladesh. Int. Food Res. J. 20 (2): 1011-1015.

12. Khanam N, Mia MY, Zubair A, Real MKH. 2018. Microbial and chemical quality analysis of industrially processed mango juice available in Tangail Sadar Uazila, Bangladesh. Annals Food Sci. Techn. 19 (2): 333-340.

13. Jayalakshmi T, Krishnamoorthy P, Kumar RG, Sivamani P. 2011. The Microbiological Quality of Fruit containing Soft Drinks from Chennai. J. Chem. Pharma. Res. 3 (6): 626-630.

14. Food Code. 2017. Recommendations of the United States Public Health Service Food and Drug Administration. Annex 4 management of food safety practices achieving active managerial control of foodborne illness risk factors.

15. Connell PM, Finkelstein SR, Scott ML, Vallen B. 2017. Handbook of Famine, Starvation, and Nutrient Deprivation. Springer, Cham.

16. Choi JY, Lee HJ, Cho JS, Lee YM, Woo JH, Moon KD. 2017. Predication of shelf- life and change in the quality characteristics of semidried persimmons stored at different temperature. Food Sci. Biotechnol. 26 (5): 1255- 1262.

17. Sperber WH. 2009. Compendium of the Microbiological Spoilage of Foods and Beverages. Food Microbiology and Food Safety. Springer, New York, NY.

18. Das KK, Fatema KK, Nur IT, Noor R. 2013. Prevalence of microorganisms in commonly used cosmetics samples in Dhaka metropolis. J. Pharma. Sci. Inno. 2 (6): 7-9.

19. Skowron K, Jakubicz A, Budzyńska A, Kaczmarek A, Grudlewska K Reśliński A, et al. 2017. Microbiological purity assessment of cosmetics used by one andseveral persons and cosmetics after their expiry date. Rocz. Panstw. Zaki. Hig. 68 (2): 191-197. 